\title{
Standardisation in clinical laboratory medicine: an ethical reflection
}

\author{
Xavier Bossuyt, ${ }^{1}$ Céline Louche, ${ }^{2}$ Allan Wiik ${ }^{3}$
}

Many efforts have been undertaken to standardise diagnostic tests. For example, the introduction of CRM-470, an international reference preparation for proteins in human serum ${ }^{1}$ has reduced the amonglaboratory variance of protein quantification. $^{2}$ (The examples provided are from the field of Clinical Laboratory Immunology and Protein Chemistry.) The Dutch Red Cross Institute together with the World Health Organization (WHO) prepared an international standard for quantification of antibodies to double-stranded DNA. ${ }^{3}$ The International Union of Immunological Societies (IUIS), together with the American Arthritis Foundation and the Centers of Disease Control (CDC), made available reference sera selected by the International Committee on Autoantibody Testing in Rheumatic Diseases and Related Disorders for detecting anti-nuclear antibodies. ${ }^{4}$ These initiatives improved worldwide harmonisation of laboratory test results.

However, despite efforts to harmonise laboratory tests, reference reagents are still lacking for many tests. For example, standardisation is unsatisfactory for IgG subclass determination. ${ }^{5}$

A number of promising new laboratory tests have recently become available, such as the determination of antibodies to (a) tissue transglutaminase, (b) Saccharomyces cerevisiae and (c) (cyclic) citrullinated peptides (CCP) and proteins (anti-citrullinated protein antibodies (ACPA)). These tests have been introduced without standardisation. ${ }^{6-8}$ Results obtained in different laboratories or in different clinical studies are not interchangeable, which impairs evidence-based medicine. In spite of this, there are encouraging initiatives, as more reference reagents are being

\footnotetext{
${ }^{1}$ Laboratory Medicine, University Hospitals Leuven, Belgium; ${ }^{2}$ Governance and Ethics, Vlerick Leuven Gent Manangement School, Belgium; ${ }^{3}$ Department of Autoimmunity, Statens Serum Institute, Denmark

Correspondence to: Xavier Bossuyt, Laboratory Medicine, Immunology, University Hospital Leuven, Herestraat 49, B-3000 Leuven, Belgium;

xavier.bossuyt@uz.kuleuven.ac.be
}

prepared at this moment. ${ }^{9}$ A new reference reagent for anti-CCP antibody quantification is being prepared by the IUIS Autoantibody Standardization Committee. If the material is appropriate, it will become available as a standard through CDC. New reagents for standardisation of proteinase 3 anti-neutrophil cytoplasmic autoantibodies (ANCA) and myeloperoxidase ANCA have recently been made ready for use through CDC

\section{STANDARDISATION OF IN VITRO DIAGNOSTIC ASSAYS: "ETHICAL" LAG}

The implementation of standards lags behind the development and implementation of new technologies. ${ }^{10}$ This lag could be coined "cultural" lag10 or "ethical" lag. ${ }^{11}$ The term "cultural" lag was introduced by Ogburn ${ }^{10} 12$ to describe the phenomenon that material culture advances more rapidly than non-material culture. Technology is material culture, whereas standardisation is non-material culture as it is deliberate and relies on consultation, dialogue, consensus building and adaptation between different bodies with different interests. When ethics are defined as "guidelines to influence human social behaviour in a manner intended to protect and fulfil the rights of individuals in a society", 12 then standardisation of laboratory tests has an ethical dimension as it aims to affect the way diagnostic tests are performed in order to guarantee optimal care for patients in a global world. ${ }^{13}$ "Ethical" lag occurs when the speed of technological change exceeds that of ethical development. ${ }^{11} 12$ Several factors contribute to this situation. As soon as a new technical approach proves valuable, clinical diagnostic companies develop the new technology and commercialise it. The expectation of a high profit speeds the process (competitive advantage of being the first on the market). By contrast, the development of standards is slower and requires consensus from the industry and the medical society. Cultural (ethical) lag is natural. ${ }^{12}$

\section{(LACK OF) STANDARDISATION OF CLINICAL LABORATORY DIAGNOSTIC TESTS: AN ETHICAL INVESTIGATION The conventional approach}

In the conventional approach, a practice is compared with the prevailing norms of acceptability (preferred behaviour). ${ }^{14}$ The practice we observe is that new diagnostic tests are introduced without standardisation. The prevailing norms on standardisation in clinical laboratory immunology are in favour of standardisation. This is illustrated by a WHO document on biological standardisation that states "The need for an International Biological Reference Preparation is recognized by the scientific and medical community worldwide". ${ }^{15}$ However, the general attitude from the diagnostic industry is that many tests are introduced without full standardisation. The fact that tests are not standardised is a weak "lock-in" because it makes it more difficult for laboratories to change from one commercial brand of a test kit to another. When laboratories change supplier then there is a change in values (switching cost). This might be an advantage for some companies (eg, the first and market-leading producing company for a newly developed test). Taken together, two conflicting norms are discerned: the recognition of the need for standardisation and the market for which standardisation is not the main objective.

\section{The principles approach}

The principles approach to ethics is based on the idea that decisions can be founded on solid principles. ${ }^{14}$ There are two major theories: the teleological theory (eg, utilitarianism), which focuses on the results of the actions, and the deontological theory (eg, Kant's categorical imperative), which focuses on duty.

Utilitarianism asserts that one should act so as to produce the greatest ratio of good to evil for everyone. ${ }^{14}$ It expresses morality in terms of society as a whole. For an analysis of the problem of standardisation of in vitro diagnostic tests according to the principle of utilitarianism one should distinguish the short-term perspective from the long-term perspective. Because standardisation is based on consensus it may take a long time to realise. Therefore, it may be that in the short term introducing a new non-standardised test on the market may satisfy a larger number of stakeholders than waiting with the introduction until there is standardisation. For example, even in the 
absence of an international standard, the commercial anti-CCP test has proven valuable in clinical practice. However, in the longer term non-standardisation may have a negative effect.

A second fundamental ethical principle is Kant's categorical imperative: "So act to treat humanity, whether in your own person or in that of any other, in every case as an end and never as merely a means". ${ }^{14}$ Kant's categorical imperative tells us to see patients as ends and not as means (to pursue profits). The legitimate rights of the patients must be maximally served. In the long-term patients will benefit most if laboratory tests are standardised. Therefore, in the long term, Kant's imperative argues in favour of standardisation. In the short term, however, patients and medical professionals may want to have access to innovative tests even before there is standardisation. Yet, what may be beneficial in the short term may be unfavourable in the long run. When anti-CCP was launched one could think short term. But, as time passed society should change to the long-term view.

\section{An ethical investigation from the perspective of consumer protection}

Velasque ${ }^{16}$ proposed different theories on the ethical duties of manufacturers: the contract view and the "due care" view. The contractual theory states that firms have to live up to the claims they make about their products. General concerns about the accuracy, reliability, traceability and quality of commercial kits have been raised. ${ }^{8}{ }^{17}$

The "due care" theory states that manufacturers have the duty to take special "care" to ensure that consumers' interests are not harmed by the products (eg, test results) they offer them. In keeping with the "due care" theory diagnostic companies, together with all other parties involved, should undertake efforts to standardise their assays. Additionally, clinical laboratories have a responsibility to implement the assays in a proficient way. ${ }^{17}$ Even if the same product is used, there may be great variations in the results obtained by different people handling the product. ${ }^{17-19}$ Laboratories should follow the manufacturer's protocols, adhere to standard operating procedures, and use international reference sera. ${ }^{17}$ Switching from one to another methodology obviously also has an effect on results. ${ }^{20-22}$

\section{STANDARDISATION OF DIAGNOSTIC LABORATORY TESTS: AN OPPORTUNITY FOR SOCIAL RESPONSIBILITY}

Engaging in standardisation is a chance to help the industry set higher standards ${ }^{13} 1722$ and better fulfilling its societal role. If diagnostic companies want to be successful in the long run they must address the expectations of society. ${ }^{14}{ }^{23}$ According to the code of ethics of the European Diagnostic Manufacturers Association, the medical diagnostic industry has a responsibility to contribute to the safety and well-being of patients and the improvement of healthcare systems. ${ }^{24}$ Patients are the most important interest group of the medical diagnostic industry. Companies seek to make profit out of health while at the same time strive to meet the need of patients for better and safer diagnostics. They, therefore, have a special responsibility in society.

Standardisation should include regulators, users, professional organisations and industry. Standardisation is a long process and companies sometimes have the impression that the willpower of reference institutions is limited.

The introduction of a new test constitutes an opportunity to engage in standardisation. ${ }^{25}$ A survey of Deutsches Institut für Normung (DIN) revealed that participating in standardisation has benefits for business (eg, strategic alliances, improved client relationships). ${ }^{26}$

It should be mentioned that in medical diagnostics standardisation involves the development of a physical sample for each analyte as an international reference material. This implies that international standards are periodically exhausted and that standards can only be developed when a high level of understanding of what the actual biological sample is physically has been ascertained.

\section{THE ROLE OF GOVERNMENT, FEDERAL AGENCIES, PROFESSIONAL ORGANISATIONS AND PATIENT ORGANISATIONS IN STANDARDISATION OF DIAGNOSTIC TESTS}

Government provides huge amounts of money for social security and health care insurance. Therefore, government should attempt to encourage health care business to act in the general interest of the patients.

There is an added social responsibility inherent in producing and selling medical diagnostic products. Goals such as obtaining interchangeable test results have not been automatically considered by the industry. It often falls on government (regulatory bodies), WHO, CDC, or other (professional) organisations (Joint Committee for Traceability in Laboratory Medicine (JCTLM)) to ensure that those goals be achieved. ${ }^{14}$ Federal regulatory agencies could establish standards or guidelines or could impose restrictions on business conduct. ${ }^{14}$ For example, approval or reimbursement of diagnostic tests could be made dependent on the clinical relevance of the test and efforts to harmonise test results. Additionally, patients should be engaged in standardisation efforts. Patient organisations should demand changes in favour of standardisation. Similarly, ethical standards of institutional research ethics boards should encourage standardisation.

\section{TOWARDS A HARMONISED DIAGNOSTIC PROCESS: ADJUSTMENTS OF ASSAYS TO MEET THE DEMAND OF CLINICAL DIFFERENTIAL DIAGNOSTICS - A CALL FOR CLOSE COLLABORATION BETWEEN LABORATORY PROFESSIONALS AND CLINICIANS}

Standardisation of commercial kits should be a first step in harmonisation of the whole diagnostic value chain. For a laboratory test to be truly useful for diagnostics of a certain disease it is important that test results allow the distinguishing of one group of patients from patients with related disorders. For example, a new assay to detect a particular autoantibody associated with a certain phenotype (eg, a specific ANA) must first be tested using a test battery of sera from patients with various chronic inflammatory rheumatic conditions. ${ }^{132}$ Resetting of the cut-off may be necessary in order for the test to be specific towards other inflammatory diseases. The kit provider usually determines a cut-off value based on analysis of sera obtained from healthy controls. Another way of ensuring clinically valuable information from a test system may be to re-test sera found to contain borderline positive values of the particular antibody using a different assay. Alternatively, reports of borderline positive values should contain information that the result is unlikely to have the same diagnostic value as a clear positive result. Some people prefer to ask the clinic to send another serum for testing at a later date. Decisions on how to handle such situations must be based on mutually agreed guidelines between clinical and laboratory scientists. ${ }^{13}{ }^{27}$ If guidelines could be harmonised between countries, with due reference to the different conditions guiding diagnostics in each country, high quality diagnostics would be a likely result. ${ }^{27}$ 


\section{CONCLUSIONS}

In summary, there is a natural conflict between the rapid pace by which new technology is introduced and the slower pace by which standards are developed. The challenge for the diagnostic industry, authorities, standardisation bodies, patients and the medical community will be to close this gap by more generalised efforts to produce international standards. Standardisation will harmonise laboratory results and support evidence-based medicine in a global world. Clinicians and laboratory professionals should closely collaborate in order to harmonise the diagnostic process and guidelines should be harmonised across countries.

Acknowledgements: We are grateful to Jesús Rueda Rodriguez, Regulatory Affairs Officer, European Diagnostic Manufacturers Association for helpful discussions. Permission was granted by the organisers and editor/publisher of the 2006 shortlisted essays (The responsibilities of business in a knowledge society (http://www.ashridge.org.uk)) of the Ashridge best European MBA essay award in association with the European Academy of Business in Society supported by Microsoft to reuse and adapt some parts of the content of an essay submitted to the Ashridge essay award and selected for the shortlist in this work.

Competing interests: None.

Accepted 30 March 2008

Ann Rheum Dis 2008;67:1061-1063.

doi:10.1136/ard.2007.084228

\section{REFERENCES}

1. Whicher JT, Ritchie RF, Johnson AM, Baudner S, Bienvenu J, Blirup-Jensen S, et al. New international reference preparation for proteins in human serum (RPPHS). Clin Chem 1994:40:934-8.

2. Johnson AM, Whicher JT. Effect of certified reference material 470 (CRM 470) on national quality assurance programs for serum proteins in Europe. Clin Chem Lab Med 2001;39:1123-8.
3. Feltkamp TE. Standards for ANA and anti-DNA. Clin Rheumatol 1990;9(Suppl 1):74-8.

4. Tan EM. International cooperative activities in standardization of antinuclear antibodies. In: Van Venrooij WJ, Maini RN, eds. Manual of biological markers of disease. Dordrecht, The Netherlands: Kluwer Academic Publishers, 1993:A1-1-5.

5. Bossuyt X, Marien G, Meyts I, Proesmans M, De Boeck K. Determination of IgG subclasses: a need for standardization. J Allergy Clin Immunol 2005; 115:872-4

6. Vermeire S, Joossens S, Peeters M, Monsuur F, Marien G, Bossuyt X, et al. Comparative study of ASCA (anti-saccharomyces cerevisiae antibody) assays in inflammatory bowel disease. Gastroenterology 2001;120:827-33.

7. Van Meensel B, Hiele M, Hoffman I, Vermeire S, Rutgeerts P, Geboes K, et al. Diagnostic accuracy of ten second-generation (human) tissue transglutaminase antibody assays in celiac disease. Clin Chem 2004;50:2125-35.

8. Coenen D, Verschueren P, Westhovens R, Bossuyt X. Technical and diagnostic performance of 6 assays for the measurement of citrullinated protein/peptide antibodies in the diagnosis of rheumatoid arthritis. Clin Chem 2007:53:498-504.

9. Committee of Autoantibody Standardization International Union of Immunological Societies http://www.autoab.org (accessed 1 May 2007).

10. Ogburn WF. Cultural lag as theory. In William $F$ Ogburn on culture and social change. Chicago, Illinois, USA: Phoenix books/The University of Chicago Press, 1964:86-95.

11. Kracher B, Corritore CL. Is there a special ecommerce ethics? Business Ethics Quarterly 2004;14:71-94.

12. Marshall KP. Has technology introduced new ethical problems? J Business Ethics 1999;19:81-90.

13. Wiik A, Gordon TP, Kavanaugh AF, Lahita RG, Reeves W, van Venrooij WJ, et al. Cutting edge diagnostics in rheumatology: the role of patients, clinicians, and laboratory scientists in optimizing the use of autoimmune serology. Arthritis Care Res 2004;51:291-8

14. Carroll B, Buchholtz AK. Business \& society. ethics and stakeholder management. 6th edn. Belmont, California, USA: Thomson South Western, 2006

15. World Health Organization. http://www.who.int/ bloodproducts/ref_materials/en/ (accessed 1 May 2007).

16. Velasquez MG. Business ethics: concepts and cases. 4th edn. Upper Saddle River, New Jersey, USA: Prentice Hall, 1998:335-44.
17. Fritzler MJ, Wiik A, Fritzler ML, Barr SG. The use and abuse of commercial kits used to detect autoantibodies. Arthritis Res Ther 2003:192-201.

18. Tan EM, Smolen JS, McDougal JS, Butcher BT, Conn $\mathrm{R}$, et al. A critical evaluation of enzyme immuno-assays for detection of antinuclear antibodies of defined specificities. I. Precision, sensitivity, and specificity. Arthritis Rheum 1999;42:455-64.

19. Fritzler MJ, Wiik A, Tan EM, Smolen JS, McDougal JS, Chan EK, et al. A critical evaluation of enzyme immuno-assays for detection of antinuclear antibodies of defined specificities. III. Comparative performance characteristics of academic and manufacturer's laboratories. J Rheumatol 2003;30:2374-81.

20. Smolen JS, Butcher B, Fritzler MJ, Gordon T, Hardin $\mathrm{J}$, Kalden JR, et al. Reference sera for antinuclear antibodies. 2. Further definition of antibody specificities in international antinuclear antibody reference sera by immunfluorescence and Western blotting. Arthritis Rheum 1999;40:413-18.

21. Fenger $\mathbf{M}$, Wiik $A$, Høier-Madsen M, Lykkegaard JJ, Rozenfeld T, Hansen MS, et al. Detection of antinuclear antibodies by solid-phase immunoassays and immunofluorescence analysis. Clin Chem 2004;50:2141-7.

22. Pottel H, Wiik A, Locht H, Gordon T, RobertsThomson P, Abraham D, et al. Clinical optimization and multicenter validation of antigen-specific cut-off values on the INNOLIA ANA Update for the detection of autoantibodies in connective tissue disorders. Clin Exp Rheumatol 2004;22:579-88.

23. Leisinger KM. The corporate social responsibility of the pharmaceutical industry: idealism without illusion and realism without resignation. Business Ethics Quarterly 2005;15:577-94.

24. Code of ethics. European Diagnostic Manufacturers Association. http://www.edma-ivd.be (accessed 1 June 2007).

25. Hartning $\mathbf{T}$, Harmeling S, Ventkataraman S. Innovative stakeholder relations: when "ethics pays" (and when it doesn't). Business Ethics Quarterly 2006;16:43-68.

26. Economic benefits of standardization. Summary of results, published by DIN German Institute for Standardization. http://www2.din.de/index. php?lang = en (accessed 1 May 2007).

27. Wiik A, Cervera R, Haass M, Khamashta M, Meroni $\mathrm{PL}$, Piette J-C, et al. European attempts to set guidelines for diagnostics of autoimmune rheumatic disorders. Lupus 2006;15:391-6. 